\title{
ANALISIS PDRB PROVINSI LAMPUNG DAN PENGARUHNYA TERHADAP PDB NASIONAL PERIODE 2011-2015
}

\author{
Robist Hidayat \\ Universitas Muhammadiyah Yogyakarta \\ Email: robisth96@gmail.com
}

Diterima: 02 September 2019; Direvisi: 11 November 2019; dipublikasikan: 21 Desember 2019

\begin{abstract}
This study aims to analyze the gross regional domestic product in Lampung province. As for what is being analyzed is whether there is any influence from Lampung province's GRDP with the national GDP. With the data taken namely 5 years starting in 2011-2015. By using the literature review method and analyzing existing data, it continues to be developed into a new analysis by not ruling out existing methods. The results of this study are that the GDP of each province is different so it does not become a reference in the effect of national GDP in implication.
\end{abstract}

Keywords: GRDP Analysis, Lampung Province, National GDP

\begin{abstract}
ABSTRAK
Penelitian ini bertujuan untuk menganalisis produk domestik regional bruto di provinsi Lampung. Adapun yang dianalisis yakni apakah ada pengaruhnya dari PDRB provinsi Lampung dengan PDB nasional. Dengan data yang di ambil yakni 5 tahun dimulai tahun 2011-2015. Dengan menggunakan metode kajian pustaka da menganalisis data yang sudah ada terus dikembangkan menjadi sebuah analisis yang baru dengan tidak mengesampingkan kaedahkaedah yang ada. Hasil dari penelitian ini yakni PDRB setiap provinsi berbeda beda sehingga tidak menjadi acuan dalam pengaruh PDB nasional secara implikasinya.
\end{abstract}

Kata kunci: Analisis PDRB, provinsi Lampung, PDB nasional

\section{PENDAHULUAN}

Produk Domestik Bruto (PDB) merupakan salah satu indikator makro ekonomi yang pada umumnya digunakan untuk mengukur kinerja ekonomi disuatu negara. Sedangkan untuk tingkat wilayah, baik di tingkat wilayah provinsi maupun kabupaten atau kota digunakan Produk Domestik Regional Bruto (PDRB). PDRB merupakan bagian dari PDB, sehingga perubahan PDRB yang terjadi di tingkat regional akan berpengaruh terhadap PDB atau sebaliknya (Haryanto, 2008). Selain itu PDRB adalah jumlah keseluruhan nilai tambah barang dan jasa yang dihasilkan dari semua kegiatan perekonomian diseluruh wilayah dalam periode tahun tertentu yang pada umumnya dalam waktu satu tahun. Pada perhitungan PDRB dapat menggunakan dua harga yaitu PDRB harga berlaku dan PDRB harga konstan, yang dimana PDRB harga berlaku merupakan nilai suatu barang dan jasa yang dihitung menggunakan harga yang berlaku pada tahun tersebut, dan PDRB harga konstan adalah nilai suatu barang dan jasa 
yang dihitung dengan menggunakan harga pada tahun tertentu yang dijadikan sebagai tahun acuan atau tahun dasar.

Keadaan ekonomi daerah dapat terlihat dari PDRB tersebut,dimana PDRB dapat mencerminkan suatu kondisi dan pencapaian aktivitas atau kinerja perekonomian daerah itu. Informasi ini sangat dibutuhkan sebagai bentuk dukungan di setiap kebijakan yang akan diambil oleh para pengambil keputusan mulai dari tingkat perencanaan, pelaksanaan dan juga evaluasi pencapaian pembangunan di suatu daerah. Penyusunan PDRB suatu daerah merupakan salah satu cara upaya daerah tersebut dalam memberikan informasi yang jelas tentang gambaran pembangunan, situasi, kondisi dan serta potensi suatu daerah sehingga memudahkan pemerintah maupun pihak swasta dalam menentukan kebijakan pembangunan di daerah tersebut. Dengan begitu maka daerah tersebut bisa berkembang dan maju sebagaimana apa yang diharapkan masyarkat.

Produk Domestik Bruto (PDB) merupakan salah satu indikator penting untuk mengetahui perkembangan perekonomian di suatunegara dalam suatu periode tertentu, baik atas dasar harga berlaku maupun atas dasar harga konstan.PDB pada dasarnya merupakan jumlah nilai tambah yang dihasilkan oleh seluruh unit usaha di suatu negara tertentu dalam periode tertentu. Jumlah nilai barang dan jasa akhir yang disediakan dari produksi harus sama dengan nilai barang yang digunakanPDB atas dasar harga berlaku menggambarkan nilai tambah barang dan jasa yang dihitung menggunakan harga yang berlaku pada setiap tahun, sedang PDB atas dasar harga konstan menunjukkan nilai tambah barang dan jasa tersebut yang dihitung menggunakan harga yang berlaku pada satu tahun tertentu sebagai tahun dasar. PDB menurut harga berlaku digunakan untuk mengetahui pergeseran, dan struktur ekonomi suatu negara.Sementara itu, PDB konstan digunakan untuk mengetahui kemampuan sumber daya dalam mendorongpertumbuhan ekonomi secara riil dari tahun ke tahun atau pertumbuhan ekonomi yang tidak dipengaruhi oleh faktor harga.PDB juga dapat digunakan untuk mengetahui perubahan harga dengan menghitung deflator PDB (perubahan indeks implisit). Indeks harga implisit merupakan rasio antara PDB menurut harga berlaku dan PDB menurut harga konstan.(bi.go.id,2016).

Perhitungan Produk Domestik Bruto secara konseptual menggunakan tiga macam pendekatan, yaitu: pendekatan produksi, pendekatan pengeluaran dan pendekatan pendapatan

\section{Pendekatan Produksi}

Produk Domestik Bruto adalah jumlah nilai tambah atas barang dan jasa yang dihasilkan oleh berbagai unit produksi di wilayah suatu negara dalam jangka waktu tertentu (umumnya triwulan dan tahunan). 17 lapangan usaha, yaitu: (1) pertanian, kehutanan dan perikanan, (2) pertambangan dan penggalian, (3) industri pengolahan, (4) pengadaan listrik, (5) pengadaan air, pengelolaan sampah, limbah dan daur ulang, (6) konstruksi, (7) perdagangan besar dan eceran, reparasi mobil \& sepeda motor, (8) transportasi dan pergudangan, (9) penyediaan akomodasi dan makan minum, (10) informasi dan komunikasi, (11) jasa keuangandan asuransi, (12) real estate, (13) Jasa Perusahaan, (14) administrasi pemerintahan, pertahanan dan jaminan sosial wajib, (15) jasa pendidikan, (16) jasa kesehatan dan kegiatan lainnya dan (17) jasa lainnya

\section{Pendekatan Pengeluaran}

(1).Pengeluaran Konsumsi Rumah tangga(2). Pengeluaran Konsumsi LNPRT(3).Pengeluaran Konsumsi Pemerintah(4) Pembentukan modal tetap domestik bruto(5). Perubahan inventori, (6) Ekspor Barang dan Jasa(7) Impor barang dan jasa

\section{Pendekatan Pendapatan}

Produk Domestik Bruto merupakan jumlah balas jasa yang diterima oleh faktor-faktor produksi yang ikut serta dalam proses produksi di suatu negara dalam jangka waktu tertentu (biasanya satu tahun). Balas jasa yang dimaksud adalah upah dan gaji, sewa tanah, bunga modal dan keuntungan; semuanya sebelum dipotong pajak penghasilan dan pajak langsung 
Volume 11, No. 3, Desember 2019, pp. 225-237

e-ISSN: 2502-5449

p-ISSN: 2085-2266

DOI : $10.30998 /$ sosioekons.v11i3.4736

lainnya. Dalam definisi ini, PDB mencakup juga penyusutan dan pajak tidak langsung neto (pajak tak langsung dikurangi subsidi). Bi.go.id (2016)

Tabel 1.

Jumlah kependudukan Provinsi Lampung 2011-2015

Jumlah Rumah Tangga Menurut Kabupaten/Kota di Provinsi Lampung, 2011 - 2015

\begin{tabular}{|c|c|c|c|c|c|}
\hline \multirow{2}{*}{ Kabupaten/Kota } & \multicolumn{5}{|c|}{ Jumlah Rumah Tangga } \\
\hline & 2011 & 2012 & 2013 & 2014 & 2015 \\
\hline (1) & (2) & (3) & (4) & (5) & (6) \\
\hline Lampung Barat & 77.159 & 78.232 & 79.318 & 80.418 & 81.532 \\
\hline Tanggamus & 133.263 & 136.285 & 139.374 & 142.532 & 145.759 \\
\hline $\begin{array}{l}\text { Lampung } \\
\text { 3. Selatan }\end{array}$ & 236.003 & 240.916 & 245.927 & 251.039 & 256.255 \\
\hline 4. $\quad$ Lampung Timur & 256.238 & 259.884 & 263.578 & 267.321 & 271.113 \\
\hline $\begin{array}{ll}\text { 5. } & \text { Lampung } \\
\text { Tengah }\end{array}$ & 313.181 & 318.248 & 323.397 & 328.622 & 333.928 \\
\hline Lampung Utara & 145.516 & 147.610 & 149.734 & 151.886 & 154.066 \\
\hline 7. Way Kanan & 107.342 & 109.748 & 112.205 & 114.716 & 117.282 \\
\hline $\begin{array}{ll}\text { 8. } & \text { Tulang Bawang }\end{array}$ & 107.711 & 110.698 & 113.767 & 116.919 & 120.158 \\
\hline 9. $\quad$ Pesawaran & 101.338 & 103.285 & 105.267 & 107.286 & 109.342 \\
\hline 10. $\quad$ Pringsewu & 93.713 & 95.143 & 96.593 & 98.065 & 99.558 \\
\hline $12 \quad$ Mesuji & 50.842 & 51.703 & 52.577 & 53.465 & 54.368 \\
\hline $\begin{array}{lll}13 & \begin{array}{l}\text { Tulang } \\
\text { Barat }\end{array}\end{array}$ & 67.240 & 68.517 & 69.817 & 71.141 & 72.490 \\
\hline 14. Pesisir Barat & 33.070 & 33.748 & 34.439 & 35.144 & 35.863 \\
\hline $\begin{array}{ll}\text { 15. } & \text { Bandar } \\
\text { Lampung }\end{array}$ & 213.576 & 217.674 & 221.848 & 226.100 & 230.429 \\
\hline 16. Metro & 36.961 & 37.719 & 38.492 & 39.281 & 40.084 \\
\hline Lampung & 1.973 .153 & 2.009 .410 & 2.046 .333 & 2.083 .935 & 2.122.227 \\
\hline
\end{tabular}

Sumber : BPS Provinsi Lampung

Dari tabel di atas bisa di katakna bahwa setiap tahun kabupaten di provinsi lampung mengalami pertumbuhan jumnlah yga cukup signifikan, misalkan sebagai contoh kota bandar lampung, di tahun 2011 sebanyak 213.576 rumah tangga hingga tahun 2015 mengalami kenaikan sangat singnifikan yakni mencapai 230.429 ini membuktikan selama 5 tahun kota bandar lampung mengalami kenaikan sebanyak 16.853 tumah tangga.

\section{Pertumbuhan Ekonomi Lampung Tri-Wulan 2016}

Perekonomian Lampung triwulan I-2016 yang diukur berdasarkan Produk Domestik Regional Bruto (PDRB) atas dasar harga berlaku mencapai Rp 66,66 triliun, dan atas dasar harga konstan mencapai Rp. 51,06 triliun. Ekonomi Lampung triwulan I-2016 tumbuh 5,05 persen menguat dibanding triwulan yang sama tahun sebelumnya (y on y) sebesar 4,91 
persen. Dari sisi produksi, pertumbuhan tertinggi dicapai oleh lapangan usaha Pengadaan Listrik dan Gas; Konstruksi; serta Informasi dan Komunikasi. Dari sisi pengeluaran pertumbuhan tertinggi dicapai oleh Komponen Pengeluaran Konsumsi Pemerintah sebesar 8,99 persen, diikuti oleh Pembentukan Modal Tetap Bruto (PMTB) sebesar 5,61 persen dan pengeluaran Konsumsi Rumah Tangga sebesar 5,33 persen . Ekonomi Lampung triwulan I2016 mengalami peningkatan 6,51 persen dibandingkan triwulan sebelumnya (q-to-q). Dari sisi produksi, beberapa komoditi pertanian tanaman pangan dan holtikultura mulai memasuki masa panen, sehingga mengalami pertumbuhan ekspansif 38,11 persen. Secara spasial, pertumbuhan ekonomi wilayah Pulau Sumatera triwulan I-2016 tumbuh sebesar 4,18 persen dan pertumbuhan tertinggi di Provinsi Sumatra Barat yang tumbuh 5,48 persen (Berita Resmi Statistik No.09/05/18/Th.XVII, 4 Mei 2016 3)

\section{PDRB menurut Lapangan Usaha}

Pertumbuhan Ekonomi Triwulan I-2016 Terhadap Triwulan I-2015 (y-on-y)Pada triwulan I-perekonomiLampungtumbuh 5,05 persen bila dibandingkan triwulan I-2015(y-on-y). Pertumbuhan meningkat didukungoleh seluruh lapangan usaha. Tiga lapangan usaha dengan pertumbuhan tertinggi adalah Pengadaan Listrik dan Gas yang tumbuh sebesar 25,56 persen, diikuti Konstruksi sebesar 19,07 persen serta Informasi dan Komunikasi sebesar 11,28 persen. Struktur perekonomian Provinsi Lampung pada triwulan I-2016 masih didominasi oleh tiga lapangan usaha utama yaitu: Pertanian, Kehutanan dan Perikanan (33,90 persen); Industri Pengolahan (17,81 persen); serta Perdagangan Besar-Eceran dan Reparasi Mobil-Sepeda Motor $(10,72$ persen $)$.

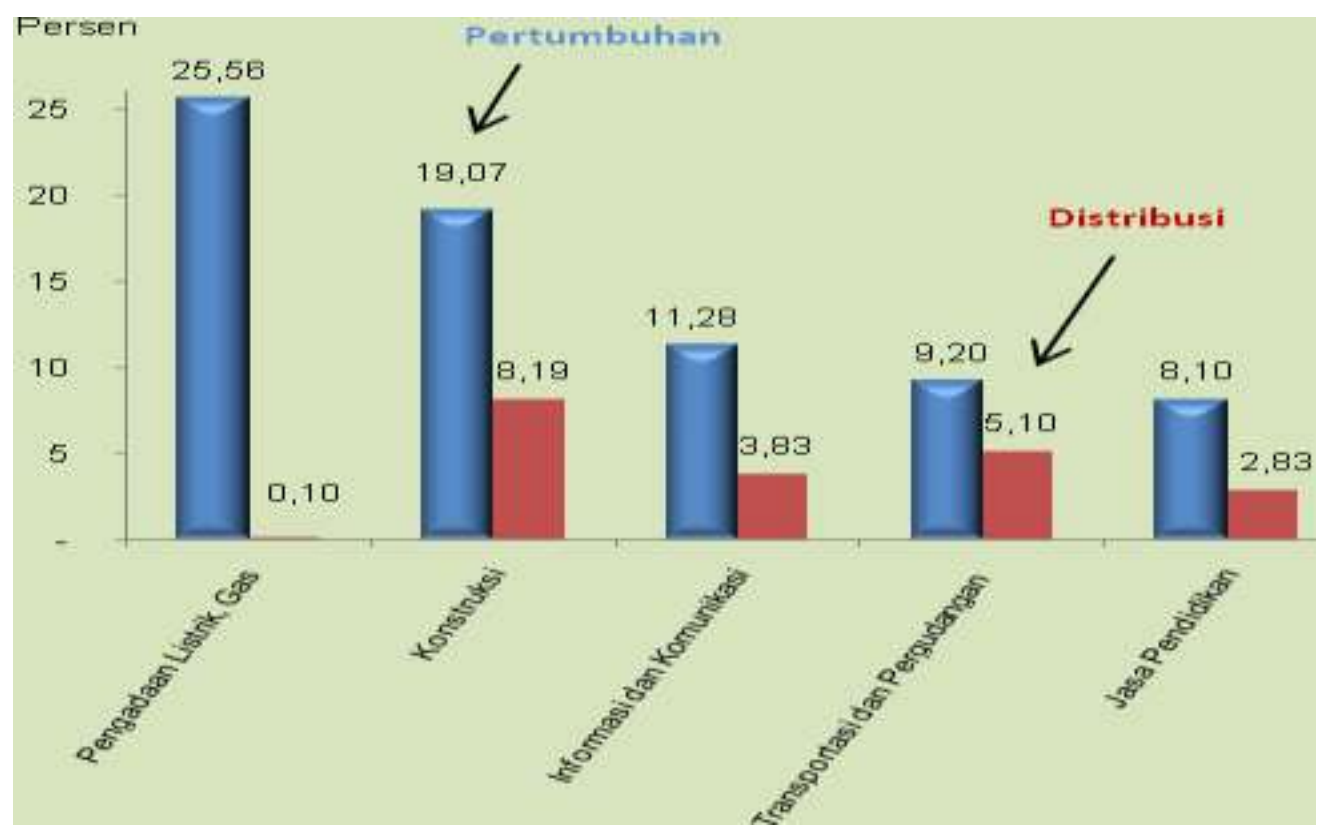

Grafik 1. Pertumbuhan dan Distribusi Beberapa Lapangan Usaha 2016 Perikanan 
Volume 11, No. 3, Desember 2019, pp. 225-237

e-ISSN: 2502-5449

p-ISSN: 2085-2266

DOI : $10.30998 /$ sosioekons.v11i3.4736

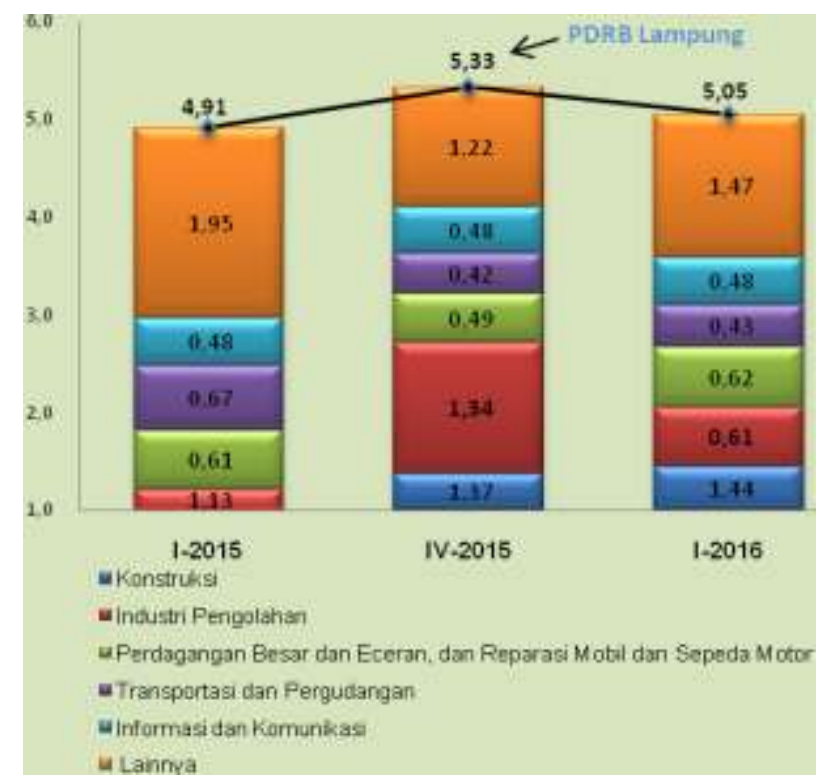

Grafik 2. Sumber Pertumbuhan Ekonomi Menurut Lapangan Usaha

Bila dilihat dari penciptaan sumber pertumbuhan ekonomi Provinsi Lampung pada triwulan I-2016 (y on y), Konstruksi memiliki sumber pertumbuhan tertinggi sebesar 1,44 persen, diikuti Perdagangan Besar-Eceran dan Reparasi Mobil- Sepeda Motor, serta Industri Pengolahan yang masing- masing tumbuh 0,6 persen

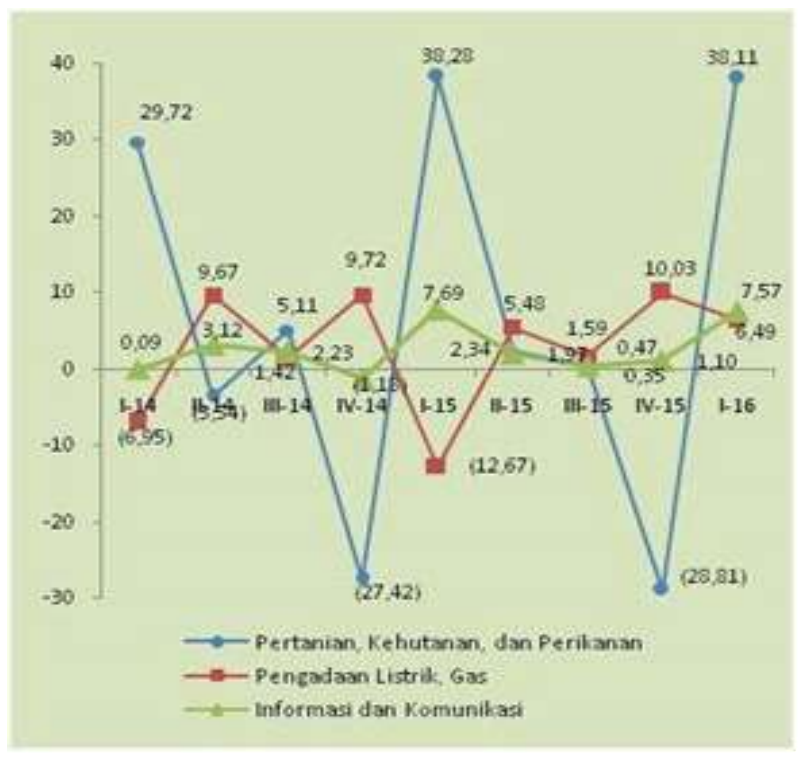

Grafik 3. Pertumbuhan PDRB q to qMenurut Lapangan Usaha

Pertumbuhan ekonomi Lampung triwulan I-2016 (q to q) diwarnai oleh faktor musiman pada lapangan usaha Pertanian, Kehutanan dan Perikanan yang tumbuh ekspansif sebesar 38,11 persen. Hal ini didorong oleh efek musiman beberapa komoditi Pertanian, Kehutanan dan Perikanan seperti padi, dan jagung yang memasuki musim panen raya dan hasil panen meningkat dari sebelumnya. Pertumbuhan juga terjadi pada beberapa lapangan usaha lainnya, seperti Informasi dan Komunikasi sebesar 7,57 persen, dan Pengadaan Listrik dan Gas sebesar 
6,49 persen. Hal ini menyebabkan ekonomi Lampung tumbuh positif 6,51 persen pada triwulan I-2016 dibanding triwulan sebelumnya. Meskipun juga ada beberapa lapangan usaha berkontribusi besar yang mengalami kontraksi, seperti Konstruksi; Administrasi Pemerintahan, Pertahanan dan Jaminan Sosial; Industri Pengolahan; dan Perdagangan Besar-Eceran dan Reparasi Mobil-Sepeda Motor.

\section{PDRB Provinsi Lampung periode 2011-2015}

PDRB Provinsi Lampung periode 2011-2015 menggunakan pendekatan PDRB menurut lapangan usaha dan PDRB atas dasar harga konstan 2010 menurut lapangan usaha. Data bersumber dari website resmi BPS Provinsi Lampung.

Tabel 2

PDRB Lampung atas Dasar Harga berlaku menurut Lapangan Usaha Periode 2011-2015 (Juta Rupiah)

\begin{tabular}{lr}
\hline \multicolumn{1}{c}{ Lapangan Usaha } & Total 2011-2015 \\
\hline Pertanian, kehutan dan perikanan & 34.627 .543 .746 \\
\hline Pertambangan dan pengalian & $5,041.915 .038$ \\
\hline Industri pengolahan & 18.857 .489 .009 \\
\hline Electricity dan gas & 72.478 .070 \\
\hline Pengadaan air,pengolaan sampah dan lainnya & 107.790 .297 \\
\hline Kontruksi & 7.521 .423 .574 \\
\hline Perdagangan besar dan reparasi kendaraan & 11.829 .416 .498 \\
\hline Transportasi dan pergudangan & 3.691 .631 .902 \\
\hline Penyedia akomodasi makan dan minum & 1.473 .652 .676 \\
\hline Informasi dan komunikasi & 3.653 .639 .491 \\
\hline Jasa keuangan dan asuransi & 2.335 .036 .754 \\
\hline Real estat & 2.930 .939 .642 \\
\hline Jasa perusahaan & 147.699 .731 \\
\hline Administrasi pemerintah dan lainnya & 3.567 .558 .981 \\
\hline Jasa pendidikan & 2.909 .196 .968 \\
\hline Jasa kesehatan dan kegiatan sosial & 978.219 .407 \\
\hline Jasa lainnya & 863.838 .184 \\
\hline PDRB & 104.592 .942 .332 \\
\hline
\end{tabular}

Adapun analisis yang dapat dibuat jika dilihat dari tabel tersebut yakni, provinsi lampung mempunyai potensi pertanian, kehutanan dan perikana yang besar dimana hal tersebut menyumbnag pendapatan sebesar 34.627.543.746. ini membuktikan bahwa didaerah provinsi lampung tersebut lebih kecenderuangan terhadap hasil alam. Dan ini merupakan faktor terbesar yang dimiliki oleh provinsi lampung. Kemudian setelah pertanian,kehutanan dan perikanan diikuti oleh industri pengolahan sebesar 18.857.489.009. faktor pendapatan terbesar kedua yakni idstri pengolahan tidak dipungkiri bahwa lampung merupaka salah satu provinsi tujuan banyak didirikan industri baik secara lokal maupun nasinla karena itu menyumbnagkan pendapatan sebesar kedua setelah pertanian dan selanjutnya bisa dilohat ditabel diatas. Dengan hasil tersebut dalam jangka waktu dari tahun 2011-2015 PDRB ynag didapati oleh provinsi lampung dari 17 item harga berlaku lapangan usaha maka didapati PDRB ecara keseluruhan yakni sebesar 104.592.942.332. 
Volume 11, No. 3, Desember 2019, pp. 225-237

e-ISSN: 2502-5449

p-ISSN: 2085-2266

DOI : $10.30998 /$ sosioekons.v11i3.4736
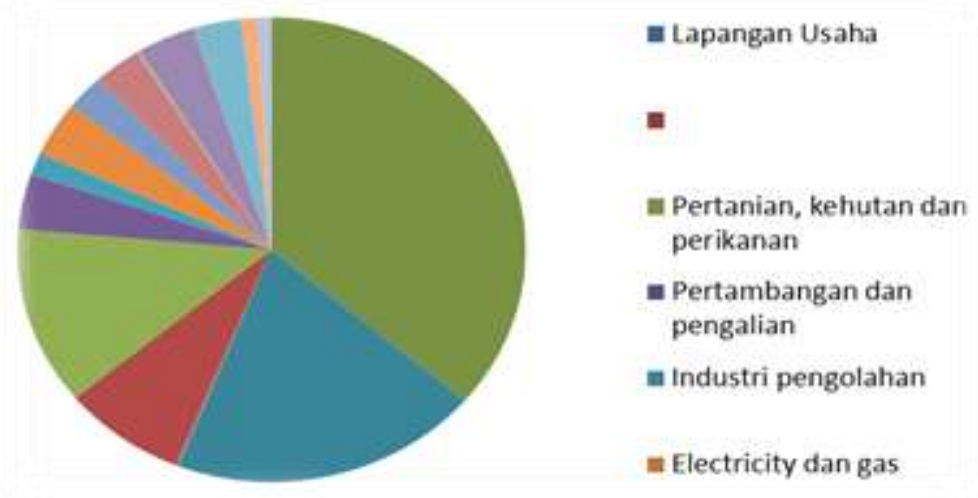

Grafik 4. PDRB Lampung Atas Dasar Harga Berlaku Menurut Lapangan Usaha Periode 2011-2015 (Juta Rupiah)

Dari grafik diatas punsudah terlihat bahwa sektor petanian,kehutanan dan perikaana merupakan penyumbang terbesar dalam hal PDRB provinsi lampung kemudian diikuti oleh sektor yang lain yang saling menunjang.

Tabel 3.

PDRB Lampung Atas Dasar Harga Konstan 2010 Menurut Lapangan Usaha Periode 2011-2015 (juta rupiah)

\begin{tabular}{lr}
\hline \multicolumn{1}{c}{ Lapangan Usaha } & Total 2011-2015 \\
\hline Pertanian, kehutan dan perikanan & 24.279 .109 .351 \\
\hline Pertambangan dan pengalian & $5,521.839 .362$ \\
\hline Industri pengolahan & 15.812 .507 .952 \\
\hline Electricity dan gas & 88.193 .970 \\
\hline Pengadaan air,pengolaan sampah dan lainnya & 94.035 .570 \\
\hline Kontruksi & 7.983 .996 .229 \\
\hline Perdagangan besar dan reparasi kendaraan & 10.789 .959 .158 \\
\hline Transportasi dan pergudangan & 4.111 .827 .110 \\
\hline Penyedia akomodasi makan dan minum & 1.134 .823 .507 \\
\hline Informasi dan komunikasi & 3.490 .390 .926 \\
\hline Jasa keuangan dan asuransi & 1.980 .140 .100 \\
\hline Real estat & 2.625 .001 .462 \\
\hline Jasa perusahaan & 120.349 .567 \\
\hline Administrasi pemerintah dan lainnya & 2.792 .407 .542 \\
\hline Jasa pendidikan & 5.502 .503 .559 \\
\hline Jasa kesehatan dan kegiatan sosial & 837.257 .084 \\
\hline Jasa lainnya & 756.699 .058 \\
\hline PDRB & 243.814 .213 .495 \\
\hline
\end{tabular}

Adapun analisis yang dapat dibuat jika dilihat dari tabel tersebut yakni, provinsi lampung mempunyai potensi pertanian, kehutanan dan perikana yang besar dimana hal tersebut menyumbnag pendapatan sebesar 24.279.109.351ini membuktikan bahwa didaerah provinsi lampung tersebut lebih kecenderuangan terhadap hasil alam. Dan ini merupakan faktor terbesar yang dimiliki oleh provinsi lampung. Kemudian setelah pertanian,kehutanan dan perikanan diikuti oleh industri pengolahan sebesar 15.812.507.952, faktor pendapatan terbesar kedua yakni industri pengolahan tidak dipungkiri bahwa lampung merupakan salah satu provinsi 
tujuan banyak didirikan industri baik secara lokal maupun nasinla karena itu menyumbnagkan pendapatan sebesar kedua setelah pertanian dan selanjutnya bisa dilohat ditabel diatas. Dengan hasil tersebut dalam jangka waktu dari tahun 2011-2015 PDRB ynag didapati oleh provinsi lampung dari 17 item harga konstan lapangan usaha maka didapati PDRB secara keseluruhan yakni sebesar 243.814.213.495 jika menilisik dari harga berlaku maka PDRBnya lebih besar dubandingkan oleh harga berlaku dengan begini maka hasil dari hasil konstan lebih besar dari hasil berlaku. Namun dari segi urutan terbesar tetap sektor pertanian,kehutan dan perikanan yang emempunyai peranan vital untuk provinsi lampung, karena merupakan pendapatan terbesar di provinsi tesebut.

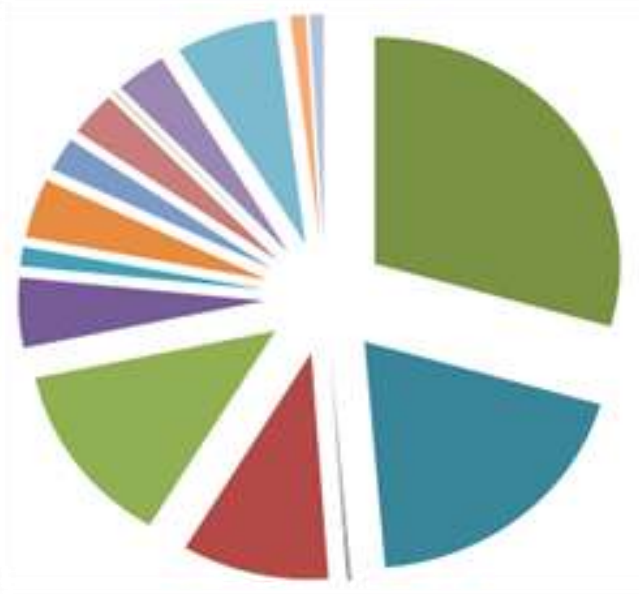

Lapangan Usaha

- Pertanian, kehutan dan
perikanan
= Pertambangan dan
pengalian
= Industri pengolahan

Electricity dan gas

Grafik 5. PDRB Lampung Atas Dasar Harga konstan Menurut Lapangan Usaha Periode 2011-2015 (juta rupiah)

Dari grafik diatas pun sudah terlihat bahwa sektor petanian,kehutanan dan perikaana merupakan penyumbang terbesar dalam hal PDRB provinsi lampung kemudian diikuti oleh sektor yang lain yang saling menunjang. Hal ini sama persisi seperti harga berlaku tadi cuman yang membedakan yakni angka disetiap item nya dimana PDRB di harga konstan lebih besar jika dibandingkan dengan harga berlaku. Dan hasil dari grafikpun berupa walupun posisi item seperti pertanian, kehutanan dan perikan tetaplah terbesar dalam sektor penyumbnag bagi provinsi lampung.

\section{Tabel 4}

PDB Nasional Atas Dasar Harga Konstan 2010 Menurut Lapangan Usaha Periode 2011-2015 (miliar rupiah)

\begin{tabular}{lrrrr}
\hline \multicolumn{1}{c}{ Lapangan Usaha } & $\mathbf{2 0 1 1}$ & $\mathbf{2 0 1 2}$ & $\mathbf{2 0 1 3}^{*}$ & \multicolumn{2}{c}{$\mathbf{2 0 1 4} * *$} \\
\hline 1. Pertanian, Peternakan, & $\mathbf{3 1 5} \mathbf{0 3 6 , 8}$ & $\mathbf{3 2 8} \mathbf{2 7 9 , 7}$ & $\mathbf{3 3 9} \mathbf{5 6 0 , 8}$ & $\mathbf{3 5 0} \mathbf{7 2 2 , 2}$ \\
\hline 2. Kehutanan dan Perikanan & & & & \\
\hline a. Tanaman Bahan Makanan & 154153,9 & 158910,1 & 161925,5 & 164082,6 \\
\hline b. Tanaman Perkebunan & 49260,4 & 52325,4 & 54629,3 & 57245,7 \\
\hline c. Peternakan dan Hasil-hasilnya & 40040,3 & 41918,6 & 43902,3 & 45960,1 \\
\hline d. Kehutanan & 17395,5 & 17423,0 & 17442,5 & 17476,3 \\
\hline e. Perikanan & 54186,7 & 57702,6 & 61661,2 & 65957,5 \\
\hline & 0 & 0 & 0 & 0 \\
\hline
\end{tabular}


Volume 11, No. 3, Desember 2019, pp. 225-237

e-ISSN: 2502-5449

p-ISSN: 2085-2266

DOI : 10.30998/sosioekons.v11i3.4736

\begin{tabular}{|c|c|c|c|c|}
\hline 3. Pertambangan dan Penggalian & 190143,2 & 193139,2 & 195853,2 & 195425,0 \\
\hline a. Minyak dan gas bumi & 95155,2 & 91691,1 & 88789,1 & 86477,6 \\
\hline b. Pertambangan tanpa Migas. & 70814,4 & 75473,0 & 79470,0 & 79620,1 \\
\hline \multirow[t]{2}{*}{ c. Penggalian. } & 24173,6 & 25975,1 & 27594,1 & 29327,3 \\
\hline & 0 & 0 & 0 & 0 \\
\hline 4. Industri Pengolahan & 633781,9 & 670190,6 & 707481,7 & 741835,7 \\
\hline a. Industri Migas & 46757,8 & 45450,6 & 44651,3 & 43639,9 \\
\hline 1). Pengilangan Minyak Bumi & 21459,7 & 21046,5 & 21286,5 & 21566,5 \\
\hline 2). Gas Alam Cair & 25298,1 & 24404,1 & 23364,8 & 22073,4 \\
\hline b. Industri tanpa Migas & 587024,1 & 624740,0 & 662830,4 & 698195,8 \\
\hline $\begin{array}{l}\text { 1). Makanan, Minuman dan } \\
\text { Tembakau }\end{array}$ & 174566,7 & 187787,0 & 194063,0 & 208105,4 \\
\hline $\begin{array}{l}\text { 2). Tekstil, Brg. Kulit \& Alas } \\
\text { kaki }\end{array}$ & 56131,1 & 58527,1 & 62076,7 & 63536,2 \\
\hline $\begin{array}{l}\text { 3). Brg. Kayu \& Hasil hutan } \\
\text { lainnya. }\end{array}$ & 19427,4 & 18817,8 & 19980,8 & 21446,3 \\
\hline 4). Kertas dan Barang cetakan & 27930,3 & 26603,5 & 27786,1 & 29494,6 \\
\hline $\begin{array}{l}\text { 5). Pupuk, Kimia \& Barang dari } \\
\text { Karet }\end{array}$ & 75657,5 & 83598,2 & 85449,3 & 86530,8 \\
\hline $\begin{array}{l}\text { 6). Semen \& Brg. Galian bukan } \\
\text { logam }\end{array}$ & 17424,1 & 18783,4 & 19346,5 & 19640,3 \\
\hline 7). Logam Dasar Besi \& Baja & 8915,2 & 9437,4 & 10091,1 & 10515,8 \\
\hline $\begin{array}{l}\text { 8). Alat Angk., Mesin \& } \\
\text { Peralatannya }\end{array}$ & 202892,0 & 217152,1 & 240031,6 & 254564,1 \\
\hline \multirow[t]{2}{*}{ 9). Barang lainnya } & 4079,8 & 4033,5 & 4005,3 & 4362,3 \\
\hline & 0 & 0 & 0 & 0 \\
\hline 5. Listrik, Gas, dan Air Bersih & 18899,7 & 20094,0 & 21254,8 & 22423,5 \\
\hline a. Listrik & 11959,6 & 12970,9 & 14006,2 & 14872,1 \\
\hline b. Gas Kota & 4583,9 & 4696,4 & 4763,7 & 5010,0 \\
\hline \multirow[t]{2}{*}{ c. Air bersih } & 2356,2 & 2426,7 & 2484,9 & 2541,4 \\
\hline & 0 & 0 & 0 & 0 \\
\hline 6. Bangunan & 159122,9 & 170884,8 & 182117,9 & 194093,4 \\
\hline \multicolumn{5}{|l|}{0} \\
\hline 7. Perdagangan, Hotel dan Restoran & 437472,9 & 473152,6 & 501040,6 & 524309,5 \\
\hline $\begin{array}{l}\text { a. Perdagangan Besar dan } \\
\text { Eceran }\end{array}$ & 364472,1 & 396116,0 & 419251,1 & 437784,4 \\
\hline b. Hotel & 17868,6 & 19577,5 & 21321,5 & 23059,0 \\
\hline \multirow[t]{2}{*}{ c. Restoran } & 55132,2 & 57459,1 & 60468,0 & 63466,1 \\
\hline & 0 & 0 & 0 & 0 \\
\hline 8. Pengangkutan dan Komunikasi & 241303,0 & 265383,7 & 291404,0 & 318527,9 \\
\hline a. Pengangkutan & 91846,8 & 97878,8 & 104787,7 & 112570,7 \\
\hline 1). Angkutan Rel & 798,8 & 745,5 & 765,7 & 926,5 \\
\hline 2). Angkutan Jalan raya & 38339,3 & 41071,0 & 44282,6 & 47705,9 \\
\hline 3). Angkutan laut & 9157,2 & 9547,9 & 10128,9 & 10832,6 \\
\hline
\end{tabular}


Volume 11, No. 3, Desember 2019, pp. 225-237

e-ISSN: 2502-5449

p-ISSN: 2085-2266

DOI : $10.30998 /$ sosioekons.v11i3.4736

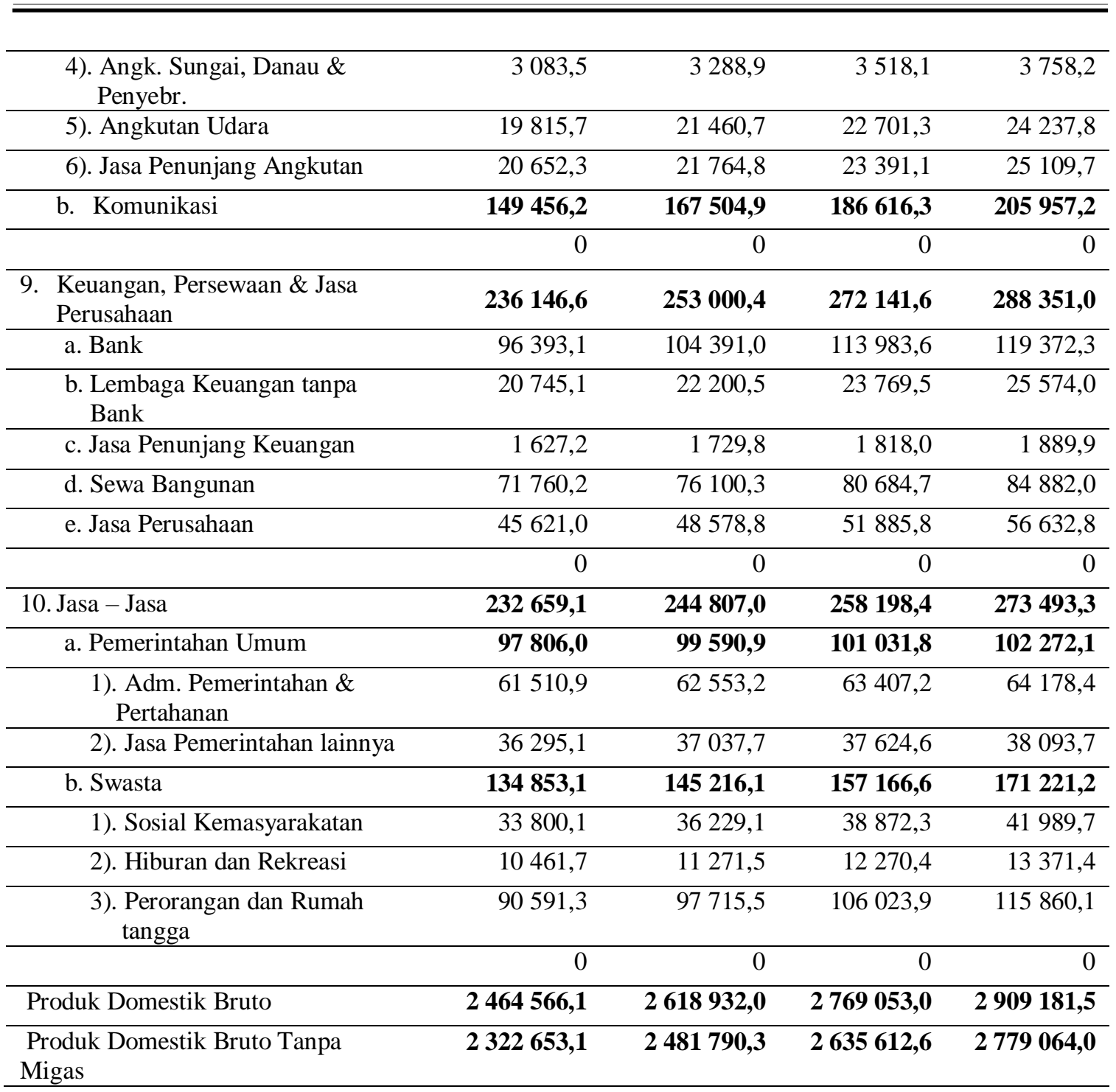

Adapun ada hubungan antara PDRB provinsi lampung dengan PDB nasional yakni: PDRB Provinsi Lampung harga konstan didapati sebesar 243.814.213.495 (juta rupiah) dihitung dari tahun 2011-2015 sedangkan PDB Nasional sebesar 104.617.326 (miliar rupiah) dari tahun 2011-2014 (- tahun 2015) hal ini jika dilihat dari hasilnya maka PDRB lampung sekitaran 5\% dari PDB Nasional.

Tabel 5

PDB Nasional atas Dasar Harga Berlaku Menurut Lapangan Usaha Periode 2011-2015 (Miliar Rupiah)

\begin{tabular}{lrrrr}
\hline \multicolumn{1}{c}{ Lapangan Usaha } & $\mathbf{2 0 1 1}$ & $\mathbf{2 0 1 2}$ & $\mathbf{2 0 1 3}$ & \multicolumn{2}{c}{$\mathbf{2 0 1 4} * *$} \\
\hline 1. Pertanian,Peternakan, & 1091447,1 & 1193452,9 & 1310427,3 & 1446722,3 \\
\hline 2. Kehutanan Dan Perikanan & 0 & 0 & 0 & 0 \\
\hline a. Tanaman Bahan Makanan & 529967,8 & 574916,3 & 621832,7 & 668337,7 \\
\hline b. Tanaman Perkebunan & 153709,3 & 162542,6 & 174638,4 & 192921,5 \\
\hline c. Peternakan dan Hasil-hasilnya & 129297,7 & 145720 & 165162,9 & 184246,5 \\
\hline
\end{tabular}


Volume 11, No. 3, Desember 2019, pp. 225-237

e-ISSN: 2502-5449

p-ISSN: 2085-2266

DOI : 10.30998/sosioekons.v11i3.4736

\begin{tabular}{|c|c|c|c|c|}
\hline d. Kehutanan & 51781,3 & 54906,5 & 56994,2 & 60872,8 \\
\hline \multirow[t]{2}{*}{ e. Perikanan } & 226691 & 255367,5 & 291799,1 & 340343,8 \\
\hline & 0 & 0 & 0 & 0 \\
\hline \multirow{5}{*}{$\begin{array}{l}\text { 3. Pertambangan dan Penggalian } \\
\text { a. Minyak dan gas bumi } \\
\text { b. Pertambangan tanpa Migas. } \\
\text { c. Penggalian. }\end{array}$} & 876983,8 & 972458,4 & 1026297 & 1058750,2 \\
\hline & 370222,9 & 386560,2 & 401139,1 & 413105,2 \\
\hline & 397629,1 & 461651 & 482823,2 & 480081,2 \\
\hline & 109131,8 & 124247,2 & 142334,7 & 165563,8 \\
\hline & 0 & 0 & 0 & 0 \\
\hline \multirow{2}{*}{$\begin{array}{l}\text { 4. Industri Pengolahan } \\
\text { a. Industri } \mathrm{M} \mathrm{i} \mathrm{g} \mathrm{a} \mathrm{s}\end{array}$} & 1806140,5 & 1972523,6 & 2152802,8 & 2394004,9 \\
\hline & 253078,6 & 254556,7 & 267003,5 & 290286,4 \\
\hline 1) Pengilangan Minyak Bumi & 131482,3 & 130273,6 & 144769,7 & 161457,8 \\
\hline 2) Gas Alam Cair & 121596,3 & 124283,1 & 122233,8 & 128828,6 \\
\hline b. Industri tanpa Migas & 1553061,9 & 1717966,9 & 1885799,3 & 2103718,5 \\
\hline $\begin{array}{l}\text { 1) Makanan, Minuman dan } \\
\text { Tembakau }\end{array}$ & 546752 & 623194,6 & 674269,4 & 776857,7 \\
\hline 2) Tekstil, Brg. kulit \& Alas kaki & 143385,2 & 156634,1 & 172422,5 & 186355,1 \\
\hline $\begin{array}{l}\text { 3) Brg. kayu \& Hasil hutan } \\
\text { lainnya. }\end{array}$ & 84481,4 & 85495,4 & 94651,1 & 106839,6 \\
\hline 4) Kertas dan Barang cetakan & 69339,6 & 67109,5 & 72781,3 & 80600,9 \\
\hline $\begin{array}{l}\text { 5) Pupuk, Kimia \& Barang dari } \\
\text { karet }\end{array}$ & 189700 & 216863,8 & 230236,1 & 242599,1 \\
\hline $\begin{array}{l}\text { 6) Semen \& Brg. Galian bukan } \\
\text { logam }\end{array}$ & 50790,5 & 57996,3 & 63973,8 & 67933,8 \\
\hline 7) Logam Dasar Besi \& Baja & 31101,1 & 33212,7 & 35746,1 & 38615,3 \\
\hline $\begin{array}{l}\text { 8) Alat Angk., Mesin \& } \\
\text { Peralatannya }\end{array}$ & 426233,7 & 465889,1 & 529828,8 & 590282 \\
\hline \multirow[t]{2}{*}{ 9) Barang lainnya } & 11278,4 & 11571,4 & 11890,2 & 13635 \\
\hline & 0 & 0 & 0 & 0 \\
\hline \multirow{5}{*}{$\begin{array}{l}\text { 4. Listrik, Gas, dan Air Bersih } \\
\text { a. Listrik } \\
\text { b. Gas Kota } \\
\text { c. Air bersih }\end{array}$} & 55882,3 & 62271,6 & 70339,6 & 81131 \\
\hline & 35443,1 & 39377,6 & 46521,5 & 54730,7 \\
\hline & 14833,9 & 16906,7 & 17379,8 & 19456,6 \\
\hline & 5605,3 & 5987,3 & 6438,3 & 6943,7 \\
\hline & 0 & 0 & 0 & 0 \\
\hline \multirow[t]{2}{*}{ 5. Bangunan } & 753554,6 & 844090,9 & 907267 & 1014540,8 \\
\hline & 0 & 0 & 0 & 0 \\
\hline \multirow{2}{*}{$\begin{array}{l}\text { 6. } \text { Perdagangan, Hotel dan Restoran } \\
\text { a. Perdagangan Besar dan Eceran }\end{array}$} & 1023724,8 & 1148791 & 1301175 & 1473559,7 \\
\hline & 827456,5 & 929746,1 & 1052709,3 & 1191231,4 \\
\hline b. Hotel & 26560,5 & 32276,6 & 39453,6 & 46970,2 \\
\hline \multirow[t]{2}{*}{ c. Restoran } & 169707,8 & 186768,3 & 209012,1 & 235358,1 \\
\hline & 0 & 0 & 0 & 0 \\
\hline \multirow{2}{*}{$\begin{array}{l}\text { 7. Pengangkutan dan Komunikasi } \\
\text { a. P e n g a n g k u t a n }\end{array}$} & 491287 & 549105,4 & 635302,9 & 745648,2 \\
\hline & 254524,2 & 287346,1 & 344485,8 & 425179 \\
\hline 1) Angkutan Rel & 2367,1 & 2478,3 & 2687,2 & 3626,4 \\
\hline
\end{tabular}


Volume 11, No. 3, Desember 2019, pp. 225-237

e-ISSN: 2502-5449

p-ISSN: 2085-2266

DOI : $10.30998 /$ sosioekons.v11i3.4736

\begin{tabular}{|c|c|c|c|c|}
\hline 2) Angkutan Jalan raya & 140603,6 & 152548,2 & 184216,1 & 220916,9 \\
\hline 3) Angkutan laut & 18589,9 & 19661,8 & 21656,3 & 25419,5 \\
\hline $\begin{array}{l}\text { 4) Angk. Sungai, Danau \& } \\
\text { Penyebr. }\end{array}$ & 7646,2 & 8765,7 & 10675,9 & 12543,2 \\
\hline 5) Angkutan Udara & 46701,8 & 62153,3 & 79038,2 & 111231,8 \\
\hline 6) Jasa Penunjang Angkutan & 38615,6 & 41738,8 & 46212,1 & 51441,2 \\
\hline \multirow{2}{*}{ b. Komunikasi } & 236762,8 & 261759,3 & 290817,1 & 320469,2 \\
\hline & 0 & 0 & 0 & 0 \\
\hline $\begin{array}{l}\text { 8. Keuangan, Persewaan \& Jasa } \\
\text { Perusahaan }\end{array}$ & 535152,9 & 598433,3 & 682973,2 & 771961,5 \\
\hline a. Bank & 166489,8 & 191095 & 224972,7 & 252216,3 \\
\hline $\begin{array}{lll}\text { b. Lembaga Keuangan tanpa } \\
\text { Bank }\end{array}$ & 70576,4 & 79807,1 & 90870,8 & 103994,7 \\
\hline c. Jasa Penunjang Keuangan & 4075,8 & 4582,2 & 5117,1 & 5662,5 \\
\hline d. Sewa Bangunan & 191928,5 & 209521,8 & 232221,7 & 258868,5 \\
\hline \multirow[t]{2}{*}{ e. Jasa Perusahaan } & 102082,4 & 113427,2 & 129790,9 & 151219,5 \\
\hline & 0 & 0 & 0 & 0 \\
\hline 9. Jasa - Jasa & 785014,1 & 889798,8 & 1000691,7 & 1108610,3 \\
\hline a. Pemerintahan Umum & 433370,9 & 486315,2 & 541191,3 & 579981,2 \\
\hline $\begin{array}{l}\text { 1) Adm. Pemerintahan \& } \\
\text { Pertahanan }\end{array}$ & 266410,1 & 300520,4 & 333960,9 & 358608,7 \\
\hline 2) Jasa Pemerintahan lainnya & 166960,8 & 185794,8 & 207230,4 & 221372,5 \\
\hline b. Swasta & 351643,2 & 403483,6 & 459500,4 & 528629,1 \\
\hline 1) Sosial Kemasyarakatan & 135184,9 & 159177,1 & 185103,2 & 215684 \\
\hline 2) Hiburan dan Rekreasi & 20455,7 & 23069,3 & 26483,8 & 31351,5 \\
\hline \multirow[t]{2}{*}{ 3) Perorangan dan Rumah tangga } & 196002,6 & 221237,2 & 247913,4 & 281593,6 \\
\hline & 0 & 0 & 0 & 0 \\
\hline Produk Domestik Bruto & 7419187,1 & 8230925,9 & 9087276,5 & 10094928,9 \\
\hline Produk Domestik Bruto Tanpa Migas & 6795885,6 & 7589809 & 8419133,9 & 9391537,3 \\
\hline \multicolumn{5}{|l|}{ Catatan: } \\
\hline \multicolumn{5}{|l|}{ * Angka Sementara } \\
\hline ** Angka Sangat Sementara & & & & \\
\hline
\end{tabular}

Adapun ada hubungan antara PDRB Provinsi Lampung dengan PDB Nasional yakni: PDRB Provinsi Lampung harga berlaku didapati sebesar 104.592.942.332 (juta rupiah) dihitung dari tahun 2011-2015 sedangkan PDB Nasional sebesar 348.323.184 (miliar rupiah) dari tahun 2011-2014 (- tahun 2015) hal ini jika dilihat dari hasilnya maka PDRB lampung sekitaran 5\% dari PDB Nasional

Berdasarkan dari pemaparan data yang di dapati bahwa Lampung memiliki potensi yang cukup besar PDRBnya di karenakan letak geografis yang sangat strategis sebagai pintu utama perdagangan serta perekonomian antara pulau jawa sebagai pusat utama ekonomi Indonesia dengan provinsi-provinsi yang ada di Pulau Sumatera. Namun tidak tertutup kemungkinan bahwa ada Provinsi lain yang lebih besar dibandingkan dengan Provinsi Lampung dan itu perlu dilakukan penelitan selanjutnya dengan rentan penelitian Provinsi yang lebih banyak tidak hanya satu saja. 


\section{SIMPULAN}

1. Provinsi lampung mempunyai potensi pertanian, kehutanan dan perikana yang besar dimana hal tersebut menyumbnag pendapatan sebesar 24.279.109.351ini membuktikan bahwa didaerah provinsi lampung tersebut lebih kecenderuangan terhadap hasil alam. Dan ini merupakan faktor terbesar yang dimiliki oleh provinsi lampung. Kemudian setelah pertanian,kehutanan dan perikanan diikuti oleh industri pengolahan sebesar 15.812.507.952 faktor pendapatan terbesar kedua yakni idstri pengolahan tidak dipungkiri bahwa lampung merupaka salah satu provinsi tujuan banyak didirikan industri baik secara lokal maupun nasinla karena itu menyumbnagkan pendapatan sebesar kedua setelah pertanian dan selanjutnya bisa dilohat ditabel diatas. Dengan hasil tersebut dalam jangka waktu dari tahun 2011-2015 PDRB ynag didapati oleh provinsi lampung dari 17 item harga konstan lapangan usaha maka didapati PDRB secara keseluruhan yakni sebesar 243.814.213.495

2. Jika dilihat dari grafik bahwa potensi besar penyumbang PDRB lampung yakni sektor pertanian dan industri hal ini yang membuat provinsi lampung mempunyai potensi potensial disektor tersebut.

3. Dari hasil analisis PDRB provinsi lampung dengan PDB nasional ,maka potensi PDRB lampung cukup besar yakni sekitaran $3 \%$ pertahunnya

\section{DAFTAR RUJUKAN}

BPS. 2011.Lampung dalam Angka 2011. Jakarta . 2012.Lampung dalam Angka 2012. Jakarta

2013.Lampung dalam Angka 2013. Jakarta

2014.Lampung dalam Angka 2014. Jakarta

2015.Lampung dalam Angka 2015. Jakarta 2016.Lampung dalam Angka 2016. Jakarta

Rino, Haryanto. 2008. Analisis Faktor-Faktor yang Mempengaruhi Jumlah Penduduk Miskin Kabupaten/Kota di Sumatera Barat. Skripsi, Fakultas Ekonomi Universitas Andalas Sukirno, Sadono.

Tri, Wahyuni Krismanti. 2009. Analisis pengaruh infrastruktur ekonomi dan sosial terhadap produktivitas ekonomi diindonesia, fakultas ekonomi dan manajemen. departement ilmu ekonomi, Institut Pertanian Bogor

Wahyunairti et al,2006. dampak petumbuhan ekonomi terhadap penurunan penduduk miskin. MB-IPB

www.bi.go.id 